\title{
Blurred Bottom lines of Ethiopian Political Crisis from 20011 to 2020
}

\author{
Jemal Muhamed Adem \\ Post Graduate Student: Department of Political Science and International Relations \\ Istanbul Sabahattin Zaim University
}

\begin{abstract}
Ethiopia has been hosting political crisis since 2011. While the dominant and official narratives emphasis on ethnicity as a sole factor to explain contemporary Ethiopian politics in general and the ongoing political crisis in particular, this paper argues that ethnic and religious determinants are deeply intertwined in Ethiopian political and conflictual dynamism. The current political transformation and related political violence and the country's upcoming future can only better explained by interplay of ethno and religious factors at local, regional and international levels. Despite the masking role of ethnicity over religious motives at least in official term, there is a tendency of developments in which the latter overwhelms the former which will expose the country for external manipulation and destabilization. The grievances that provoke ethno-religious tensions have most often demonstrated through ethnic unrests, bitter political dissidents often stoked by political elites, direct and indirect foreign actor's involvement, social media activities and violent incidents. In view of the current events unfolding in the country, the paper argued that ethnic factors alone cannot explain Ethiopia's political crisis, but ethno-religious mingles. The arguments in this paper are supported by both secondary and primary sources and with consideration of the violent incidents and their implications in multicultural contexts of Ethiopian Society.

Keywords: Ethno-religious, political crisis, Ethiopia
\end{abstract}

DOI: $10.7176 / \mathrm{IAGS} / 79-03$

Publication date: January $31^{\text {st }} 2020$

\section{Introduction}

Few years ago it was hard to predict that Ethiopian politics would change dramatically in short a period of time as the country witness now that surprises citizenries, scholars, politicians and international communities alike. Despite uncertainties about the continuation of these changes towards positive developments that will be valued by majority of Ethiopians, there is an agreement that the winds of changes are results of people's resistances against the government that takes the form either ethnic, religious or ethno religious based movements. After the brutal smash of public protests held in the capital against the regimes alleged fraud of 2005 parliamentary elections, the large scale protest against the government ignited in 2011 when Muslims community's gripe against the government's interferences the religious affairs of the religious community. While the controversy between the government and Muslim community had hushed without effective solutions, the protest sustained by a serious of ethnic based protest when ethnic Oromo in 2014, Amhara in 2016, Afar and Somalia in 2016 joined the protest and resistances politics. Amid of these popular resistance and confrontations with the government, the latter adopted various measures and internal reforms, mainly the nomination of new Prime minister, Dr Abiy Ahmed on Aprile 2, 2018. At this juncture, this paper deems that Ethiopian ethnic politics constitutes religious elements in many instances to be discussed in the following sections. While many political organizations, commentators and activists valued Muslim's resistances for the ongoing political transformation, some advocates of ethno-nationalism and leaders of other religious communities tend to derecognize the former's contribution that mostly comes from suspicious attitudes about the potential of the former's influence in the future interactions. The focus of direction is towards Ethiopian Muslim's resistance movement to the government and its externalities to ethnic based political developments and transformations and to reduce the country's political landscapes to ethnic determinants would not lead to effectively effective understanding of the country's politics. The overall objective is to show the confluences and connections between ethnicity and religion as sociopolitical determinants in contemporary Ethiopia. The key argument of the paper is that the ongoing political heats in Ethiopia are neither purely ethnic driven, as reputed officially nor free from religious based motives. To put in another words Ethnicity alone cannot explain the behavior, interest and motives of actor's Ethiopian politics.

\section{Conceptual Framework and Methodology}

Twenty first century has witnessed the rise of political significances of identities (i.e. religion, ethnicity) over political ideologies as means of channeling interests of actors in the political process of bargaining and conflicts. Moreover, developing world politics is characterized by the frequent internal conflicts and political violence either horizontally among different cultural groups or vertically between state and groups organized along identity lines. Among the other ethnicity and religion play crucial roles in galvanizing member communities to promote and advance the interests and agendas of groups into political and national affairs. It is not uncommon 
that ethnicity and religion overlaps in many instances of community's life and human interactions, the privilege position of one in socioeconomic and political life advances the other's status and influence. Likewise the contemporary political prominence of religion, Ruane \& Todd, (2010) argued, is not less important to the manner in which it intersects with ethnicity. Numerous ethnic conflicts have a strong religious dimension where religion serves either as hidden or direct force for mobilization, solidarity and fuel of violence. While both religion and ethnicity provides powerful bases of identity, group formation and communal conflict, they can also overlap in a way that "ethnic and religious boundaries, partially or completely, internally nested or intersecting" (Ruane and Todd, 2010:1).

Scholars often warned about the dangers of single factor analysis in the study of politic, violence and conflictual developments. Despite the general agreements about the complementary role of ethnicity and religion in identity politics and conflicts, there is no comprehensive theory that explains the role of ethnicity and religion in a coherent manner, the gap this paper partly deemed to address taking Ethiopian contemporary ethnic politics to reveal the religious motives masked behind ethnic controversies. The complementary role of ethnicity and religion in Ethiopian political discourse has been neglected both by scholars and policy makers either deliberately or unconsciously. The main hypothesis here is that religious and ethnic motives are mutually reinforced in Ethiopian politics with the view of ongoing political transformation that comes out of ethno religious based movements. While the purpose of this study is to give more comprehensive explanations about the intermingled nature of religious and ethnic motivations of actors in Ethiopian current political landscape, often dominated by ethno- territorial drives, the paper is based on various qualitative methods including content, document and discourse analysis. In this regard content and document analyses serve to examine the documentations and interpretations of events by various factors such as government officials, researchers end ethno-religious communities. Discourse analyses serves to evaluate the government rhetoric, social media activist's narratives and the power relationship between different actors and representation of issues in public sphere. The inertial of this paper is that the present political and ethnic violence in Ethiopia is partly an extension of the religious grievances among Muslim communities, expressed through latter's public protest against the government from 2011 to 2014 . While the paper doesn't argue that the contention between the government and Muslims is the only determinants for ongoing political instability, it equally frowns on the reduction of Ethiopian politics to Ethnic factors alone. The idea here is that as ethnicity is a legitimate means to political mobilizations, Muslims and other religious communities have been utilizing ethnicity as a means to channel their religious grievances and promote the interest of their religious communities. This is mainly because of the unwelcoming domestic and international environment of Muslims civil right movement which the government named and suppressed as fundamentalism and political moves to establish Islamic state. The discourse of fighting radicalization has been utilized by Ethiopian minority dominated authoritarian regime to convince the western governments so that the latter tolerate the former's abuses of human rights and continue financial and military supports for the last two and half decades. Domestically, the nefarious regime used the narrative of religious extremism in line with global fashion of war on terror to maintain its status in internal politics by spreading tensions and distrust among multi-ethnic and religious Ethiopian societies. Beyond Muslim's case, the paper also ruminate the oscillations of ethnicity and religious motives among other religious communities and ethnic groups.

\section{Diversity, Ethnicity, Religion and Politics in Ethiopia}

Ethiopia is home of diverse ethno-linguistic and religious communities with longstanding statehood genealogy. Following the collapse of Ethiopian Marxist regime in 1991 an ethnic coalition government known as the Ethiopian People's Revolutionary Democratic Front (EPRDF) come to power and has adopted the political orders of ethnic federalism and secularism (Serawit, 2018). The assumption behind this move was to reverse the country's established assimilationist nation building approach under the cultural hegemony of Amharic language and Orthodox Christianity. Although the assimilation project had failed with the generations of reactions from subaltern groups, the country couldn't escape from the trap of its legacies. Despite the current government's narratives of its policies as a rear of the historical prejudices by adopting de-facto multicultural approach and federalist rhetoric to the country's politics, introducing constitutional recognitions to ethno-linguistic and religious groups rights. The government restructured the country as a federation of nine regional administrations and two city administrations. While the constituent unites of the federations has drawn mainly based on ethno linguistic elements, ethnicity and religion are often tightly bounded together with geographic locations. Based on this, the main idea in this article is that religion has socially transformative roles and political implications in Ethiopian ethnic driven politics. For the purpose of this study, an emphasis is given to three religious communities and their intersections with ethnic membership; Orthodox Christianity, Islam and Protestantism due to their contemporary political significances.

On July 2017 the U.S. government has estimated the total population of Ethiopia at 105.4 million, out of which $43 \%$ adheres to the EOC, $34 \%$ are Sunni Muslim, and 19 percent belongs to Christian evangelical and Pentecostal groups. Accordingly the Orthodox Christianity predominates in the northern Regions of Tigray and 
Amhara, and Adiss Ababa while Islam is most prevalent in the Oromia, Somali Afar, and Benshangul, Regions, wollo areas of Amhara region, Gurage and Silte areas of Souther nations, nationalities and people region and Dire Dawa the second largest city of Ethiopia. Protestantism has strong base in the Southern Nations, Nationalities, and Peoples' Region, Gambela, and parts of Oromia. This shows the overlapping nature of ethnic and religious identities along administration regions which was designed based on ethnic make ups. Backing on nearly exclusive occupation of two regions Somali, Afar by Muslims, the highest share of Muslims in Oromia, the most populous and Benshangul regions, there is a discussion within the circle of Muslims that the government deliberately downsized the number of Muslims for political reasons. Thus this paper shades light on different forms of intersections between religion and ethnicity and cases where each prioritized over the others in political discourses, where each coexists in tension in political life, and where the distinctions reinforce each other with dynamic effects. It is concurrent that Ethiopia is both a country of diverse ethnic groups and a nation with high religiosity where religion and ethnic identity have symbiotic relationships in several grounds. In view of the current political developments the visible inter-ethnic unrests have a tendency to be interpreted in terms of inter-religious dimensions in the course of political disagreements.

\section{Research Questions}

How religious and ethnic factors interplay in Ethiopian political crisis from 2011-2014?

\section{Discussion and Analysis}

\subsection{Muslims protest as the background of the Resistance politics, 2011}

The year 1995 serve as an important turning point in the relation between the current Ethiopian government and Muslim communities when the former had adopted securitized approaches towards the latter that resulted in the subsequent denial of Muslims constitutional rights (Dereje, 2011). In contrary to governments move, the Muslim community has been presenting its demands to the government to change and revise its approaches and grant further rights in various ways. With the growing religious consciousness and increasing exposer to modern secular education, Muslims have been aspiring towards an Ethiopian national identity on inclusive bases (ibid). The most noticeable and comprehensive interests of Muslims has presented in 2007 by two Ethiopian Muslims diaspora organizations, called the Network (European based) and Badr (USA based) (Dereje, 2011).

The two diaspora organizations arranged a joint dialogue with the government by sending delegation composed of nine members: four from the US, three from Europe, one from Canada and one from Saudi Arabia who conducted a kind of survey and listed out what they called the crucial issues of Ethiopian Muslims articulated under a single document titled as 'Questions Rise by the Ethiopian Muslims diaspora to the Prime Minster Meles Zenawi'.

The main demands of religious community has presented in the document as: autonomy of Ethiopian Islamic Affairs Supreme Council (Mejilis), proper implementations of constitutionally granted religious equality, the need to recognize the Islamic heritage of the country, particularly Ethiopia's special role in the history of Islam so that to redefine national identity based on inclusive bases, to allow free operations of Islamic NGOs and equal treatment with Christian NGOs, allow the establishment of Islamic Banks, to respect the constitutional principle of secularism in relation to the exclusivist claim of Orthodox church over the city of Axum where Mosque construction still impossible, ensure balanced representation of Muslims in Ethiopian media, revise the impartiality of 2007 censuses which is believed to have intentionally lowered the number of Muslim population in reference with previous census. All these questions not only rejected by the government but also interpreted as a manifestation of Muslims march to control political power.

In relation to the issue of number the late prime minister in his Parliamentary Speech, on 17 April 2012 uttered beyond its expressed intent when he said: "An extremist Muslims called as salafist or Wahabist, Justifying their claim" that, "Since the majority of Ethiopian populations are Muslim (rejecting the data presented by the Central Statics Agency as false), there must be an Islamic government in Ethiopia." (Translated and quoted in Muhamed, 2016: 207). A Muslim activist Akmel Negash (2014:4), contend the argument of the Prime minister as defamation move to Muslims legitimate question, to his word "the premier openly accused Muslims for their concern of government's deliberately reduction of the number of Muslims; I don't see how it is related with a crime. Just few years ago, ethnic Amhara felt less populated and one of the ruling party's parliament members accused the government about the "deliberate cutting of numbers of the ethnic group". In a country where the number of group members has meaning of various instances, why Muslims question is associated with establishment of Islamic state".

\subsection{Muslims Public protests; Reactions to Ahbashism Imposition, 2011}

In 2011 the government's articulation the threat of fundamentalism move steps forward with the actions of the former to impose a foreign sect, "Ahbashism" under the pretext of spreading moderation among Muslims which actually was backfired with the rise of nationwide discontent among Muslims(Abbink, 2014). While the decision 
of importing the foreign sect had initiated and facilitated by external actors, particularly USA and Israel, it resulted political crisis reshuffling its patterns and scopes that partly resulted in present political transition. The act of the government was viewed as forceful indoctrinations to alien religion on the part of Muslims. Abubekr Ahmed (the leader of Muslim Solution Finding Committee, who was accused and sentenced 24 years of imprisonment for conspiring to establish an Islamic state in in 2012 and released after four years of imprisonment described the condition as: "The government's action of imposing Ahbashism up on Ethiopian Muslims is even far worse than the historical forced conversion of Wollo Muslims to Christianity by Emperior Yohanis"s IV", he further said "Yohanis was forcing Muslims in Wollo to accept the faith which at least he himself believe in, while the current government forced us to accept Ahbashim which is not even known to the government itself".

The Muslim's reactions and condemnations of government's act started when Muslim attendees of Ahbashism trainings left the session as an expression of disapproval of the proposal presented by the foreign scholars and government officials before them (Muhamed, 2013). Security forces used to collect and arrest Muslims who were not willing to sit in the training session (Abbink, 2014). This marked the open hostilities and confrontations between the EPRDF government and Muslim communities.

On December 2011 a letter was sent from Ethiopian Supreme Islamic Affairs council to Awoliya Islamic college in Adiss Ababa that stated the former's decisions about the dismissal of all Arabic teachers of the school and the suspension the Arabic curriculum (Østebø and Wallelign, 2015, Muhamed, 2016). Against this decision students of the Islamic College openly protested the government's interferences in the school and imposition of Ahbashism in the compound of the school. The event marked the beginning of large scale weekly Muslim protests, within a few days of student's protest large number of Muslim population in Adiss Ababa gathered at the college and made intensive discussions that culminated with the election of a representative committee to present interests of the religious community to the government. The committee named as "Muslims Solution Finding Committee" and articulated the demand of Muslim community in three questions briefed as:

"Stop the state-enforced al-Ahbash campaign, permit free and fair elections to the

EIASC(Mejilis), and return the Awolia College to the 'people."” (Østebø and Wallelign, 2015:

$6)$.

While the committee submitted letters to various government bodies including office of the Prime Minister, the Mejilis and Ministry of federal affairs jointly continued Ahbashism training to Muslims with the help of large number of security forces. Meanwhile Muslim community continued to express its grievances publicly particularly through weekly protests after Friday prayers. The protests by Muslim community were enormous and clearly against the regimes growing political intrusion into EIASC (majelis), devoid of religious animosity towards other religious communities (Nicolas, 2015; USCIRF, 2013). And the demands of the religious community as presented in public protests were "We want our rights!", "Stop Ahbashism campaign!" The "people want the Majlis leaders to step down!” maintaining uniformity across the country (Yunus, 2002:1). The resistances had spread beyond the capital and reached the towns of Adama, Jimma, Dessie, Gonder, Dire Dawa, Harar, Assella, Shahemene, Baddessa, Assasa, Chagni, Alaba, Woldia, Mersa, Gerba and Degan (ibid).

On the part of the government Muslims protests were portrayed as further manifestation of radical Islam with the ultimate goal to take political power by force and violence (Østebø and Wallelign, 2015:6). In April 17, 2012 parliamentary session, the late Prime Minister Meles Zenawi, told the parliament that "a few extremists are working to erode the age-old tradition of tolerance between traditional Sufi Muslims and Christians in Ethiopia" when he addressed questions related to Muslims weekly protest by one member of parliament(IRIN, 2012 ).

Ten days later, on April 27/2012 the government security forces killed seven Muslim protestors in the town of Assasa in Oromia region (Abbink, 2014). The episode in Assassa had increased countrywide tensions and Muslim's protest across the country. On 13 July, 2012 the government sent security forces to Muslims gathering in Aweliya Islamic College where the former approached towards the latter violently and arrested more than 70 people including the members of the mosque's central organizing committee (Østebø and Wallelign, 2015). After months in prison a group of 29 people including the Muslims Solution Finding Committee members were accused for "plotting acts of terrorism" in October 2012(Ibid: 6). The trials culminated in 2012 when member of Muslim's Solution Finding Committee sentenced for plot of establishing an "Islamic state" in Ethiopia. The government's act of arresting the members of Muslim's Solution Finding Committee and its accusation of them as "a terrorist" furthered the Muslim's discontents which they expressed in subsequent protests carrying the pictures of arrested members of committee, as an expression of solidarity.

The government has manipulated the state institutions, particularly communication and security sectors to defame the Muslims protests by propagating terror narratives through state run media. Worth full to mention here is the documentary film called "Jihadawi Harekat" released by the national television on 5 February 2013. The documentary portrayed the members Muslims Solution Finding Committee as terrorists and linked them with the so called regional and international terrorists groups; Boko Haram Be Etiyopiya? (Is Boko Haram in Ethiopia?) Ansardin Be Etiyopiya? (Is Ansar Din in Ethiopia?) (Muhamed, 2016). However, the documentary 
failed to convince significant portion of the audiences, both Muslims and Christians (2013).

While the documentary film has presented "untidy evidences and biased information" about the dangerous activities of Ethiopian Muslims who presented as Islamic fundamentalist in the film, many people have questioned its credibility (Abbink, 2014:256). The film entirely lacked credibility from the general public owing to its nature and timing and the honor of arrested leaders whom the documentary film depicted as an "extremists" and "terrorists" (ibid). More importantly, the lower convincing power of the documentary had come when unedited part of the film was mistakenly released without the knowledge of procedures in another program. Jep (2014: 92) stated the condition as: "an incident when the unedited scripts of the film broadcasted showing the interrogator coerce one of the representatives into admitting these things and as parts of these interviews were taken out of context in order for them to sound like what the government wanted people to hear". In this light Henoke (2013: 82) pointed out that "most participants have made reference to the 16 minutes video leaked that showed Abubeker Ahmed while his hands were in a chain and being investigated by government security officials".

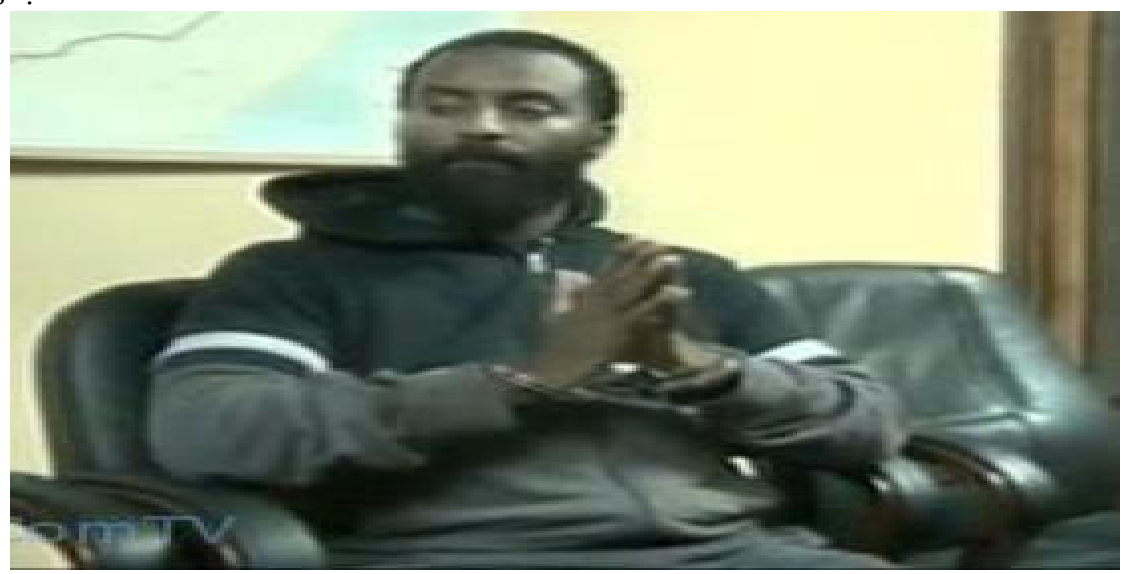

Figure 1, the documentary when leaked interrogation footage showed the chained leader.

The documentary heightened the Muslim community's hostility towards the government who adopted the symbol of crossing two hands, as in the above picture, as a symbol of resistance in public protest to show their solidarities to Muslims solution finding committee members who had presented in the documentary as terrorist group.

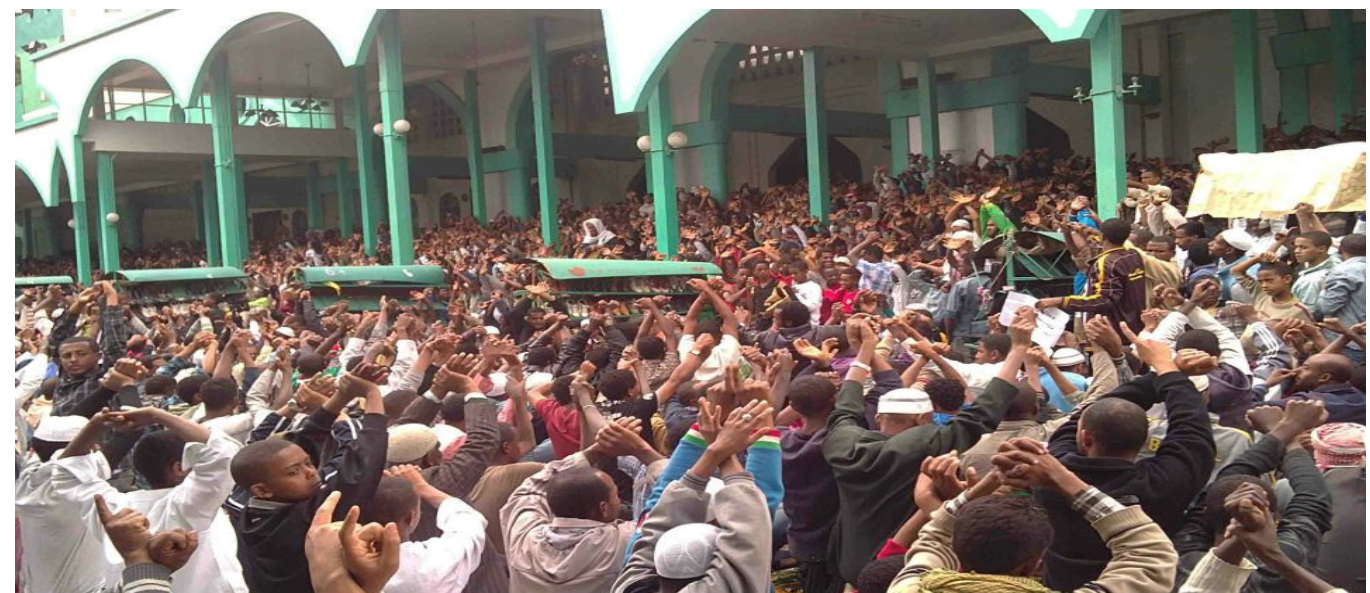

Figure 2, Muslims Protest at Grand Anwar Mosque in 2013, Adiss Ababa.

Throughout the protest security forces especially federal police assaulted and arrested hundreds of Muslims (Abbink 2014). In August 2013, security force killed eleven Muslims when they were demonstrating in Kofale, a small town $250 \mathrm{~km}$ south of Adiss Ababa (Lyons, 2015). On the day of Id al-Fitr celebrations, August 21, 2013 the Federal police attacked Muslims returning from prayers through random beating and arresting of thousands of Muslims in Adiss Ababa in order to carve mass protests. The episode marked the regime's success as it effectively put down the Muslim's open protests that has continued from 2011 (ibid).

During these years of confrontations between Muslim community and government a good deal of Christians and opposition groups, diaspora community and human right organizations support Muslims case against the government's rhetoric of elements of extremism (Abbink, 2014). Human Rights Watch, Amnesty International, bi-partisan United States Commission on International Religious Freedom (USCIRF), and State Department's Bureau of Democracy and Human Rights attributed the disputes to government's violation of constitutional 
rights and religious freedom. An exceptional case in this regard were reports by The United State Bureau of Counter Terrorism (2012), that positively associated the government's motive to undertake forceful training of Muslims to an effort to curve the growing fundamentalism sentiment within Ethiopian Muslims. This gave confidence to the government compounded with the US's position to Ethiopia as strong African mutual partner in its counter terrorism campaign despite the huge gaps between the two in the areas human rights and democracy.

\subsection{From Religious protest to Ethnic Resistance, 2014}

The official political frameworks in Ethiopia welcomes ethnic based political mobilization, whereas religious one is banned under the constitutional principle of secularism. After six months of Muslim's protest had bunged by government force violently, the country shaken by another waves of large scale protests called Oromo Protests in April and May 2014. The long time and multiple grievances among Oromo people, majority of who are Muslims, erupted when the government launched 'Addis Ababa and Oromia Special Zone Integrated Development Master Plan which was viewed as dispossession of Oromo people's property, mainly land (Amnesty International, 2017). Led by diaspora Oromo activists, notably Jawar Moahamed the Oromo protest swiftly spread across towns and universities in Oromia regional state. At this juncture the point to be made here is that religious grievances of Muslim communities in the previous years had sustained and part of ethnic based protests and political mobilizations. Proponents of ethno nationalism don't only want to recognize these religious elements but also considered the later as a threat to the unity of their ethnic group. The first indicator of sustained effects of religious community's grievances in ethnic protests went to the government's actions of mass arrest and brutal attack of huge number of Muslims in Oromia. Several thousand Oromos have been arrested in relation to a series of protests carried out by the Muslim community in 2011-2013 against alleged government interference in Islamic affairs (Amnesty International, 2017). While the 'Master Plan' issue was important around the capital city and the protest was strong and frequent in Muslim dominated areas of east and south eastern Ethiopia, where forceful Ahbashism training was undertook in the previous years. In this regard a Muslim Oromo student in Dire-dawa said that "we know for what we are fighting but this is the only right way to our ends", referring his religious grievances and ethnicity as a suitable framework to contest against the government. At this juncture an important lesson is that relying on ethnic appendages helps the people to maintain their unity and undertake organized measures against the government without which the ongoing country's transformation was unimaginable. Here ethnicity serves as a reserve of religious grievances. Again it is not meant that there are no socio-economic factors that fueled ethnic based protest across the country other than ethnicity and religion. However, ethnicity has been suitable for organized and acceptable expressions of grievances as per the context of Ethiopian politics. Government on its part has relied on forces full reactions to ethnic protests and thousands of Oromos killed brutally by the security forces in the course of protest in 2014 to 2016.

In October 2016 the government declared state of emergency as a solution for what it called the problems of instability plotted by "anti-peace or extremist" entities whose aim accordingly was turn the country into violence. In this regard, Lyons (2017: 7) argued that sustained from "non-violent mobilization by Ethiopian Muslims", more spontaneous and violent demonstrations by Oromo's resulted an emergency politics. Moreover Abbink (2014) asserted that new forms of alliances are being formed between ethnic and religious identity markers as "the boundary between ethnic and religious identities is not always mutually exclusive". In line to this, one of the leading diaspora Oromo activists Jawar Muhamed (2013) remarked that "in the long history of Ethiopia, the Oromo and Islam have common historical experiences; the victory of Oromo is the victory of Islam and vice versa". In relation to the recent political developments he said "the Oromo and Muslim protests are interrelated in various respects". As the government failed to address and deal the grievances of Muslim community which manifested mostly through non-violent public protests in 2011-2013/14, the Muslim's discontent has not without transitional effects to what Lyons, (2017:3-4) referred as;

"while the discontents with Muslim community who undertook an important peaceful demonstrations in 2012", were remain unsolved, an unprecedented and large scale violent waves of protests erupted in 2015 in Oromia and a year later in the Amhara regions"

ICG (2016:12) describe the confluences of religious, ethnic and regional clevages and grievances to reveal the symbiotic nature Muslims and Oromo protest from 2011-2017 as:

"Religion and religious tensions in Ethiopia "though in many ways unique due to the millennia-long presence of both Christianity and Islam" reflect broader regional and global trends. The country has not experienced anything like the faith-based revolutions, wars and violent extremism in neighboring Sudan, Somalia and Kenya, but perceptions of discrimination and exclusion, as well as resistance to top-down government, have been constant drivers of past social revolutions and ethno-regional rebellions"

In 2016 the protest expanded to Amahra region, the second largest region and overwhelmingly inhabited by 
followers of Orthodox Christianity. Among the adherents of Orthodox Chirstianity often circulates about the declining status of Orthodox Christianity and the regime's stand against the millennia old political favors of Orthodox Church. The grievances frequently heard on issues like the government's control of incomes from the country's major tourist's centers, The Lalibella Rock-Hewn Churches and The Obelisk of Axum in the north east and northern parts of the country respectively, the regimes attempt to confiscate parts of the waldiba monastery land for sugarcane planation, and ethnic affiliation of the incumbent head of the Ethiopian Orthodox Church to politically dominant ethnic group, Tigre. At this juncture the country's two largest ethno-national groups, the Oromo, and the Amhara have joined against the government which had dominated by minority Tigrayan ethnonational group since 1991. Given the historical controveresies between Amhara and Oromo, it is indeterminate whether the political alliances between the political elites from these ethnic groups sustain to have significant impacts or not. The fact that the contested notions of Ethiopia as understood by the two ethnic groups do not promise amicable future developments. The divergences between the two ethnic groups is not limited only ethno linguistic differences, but also rooted in factors like national symbol and heroes, political economy of land and federalism, and religious identities. The Amhara's, the former name of adherents of orthodox Christianity, understanding of Ethiopian state is largely enunciated and supported by religious narratives, Ethiopia an island of Christianity in the sea of Islam. For them the essence of Ethiopian state is Orthodox Christianity, any move to reshuffle the nations identity is against this century old establishments and their identity. For majority of Oromo's Ethiopian national identities are reflections the historical imposition of hegemonic cultural elements of Amharic language and Orthodox Christianity. Given the global trends and contexts of the overriding influences of religious identities over ethno linguistic one, it is arguable that the ethnic controversies between the two are driven by religious motives.

The dissident voices of Muslim community, ethnic Oromo, Amhara and other ethno religious communities joined from 2011-2018 against minority ethnic dominated authoritarian regime.

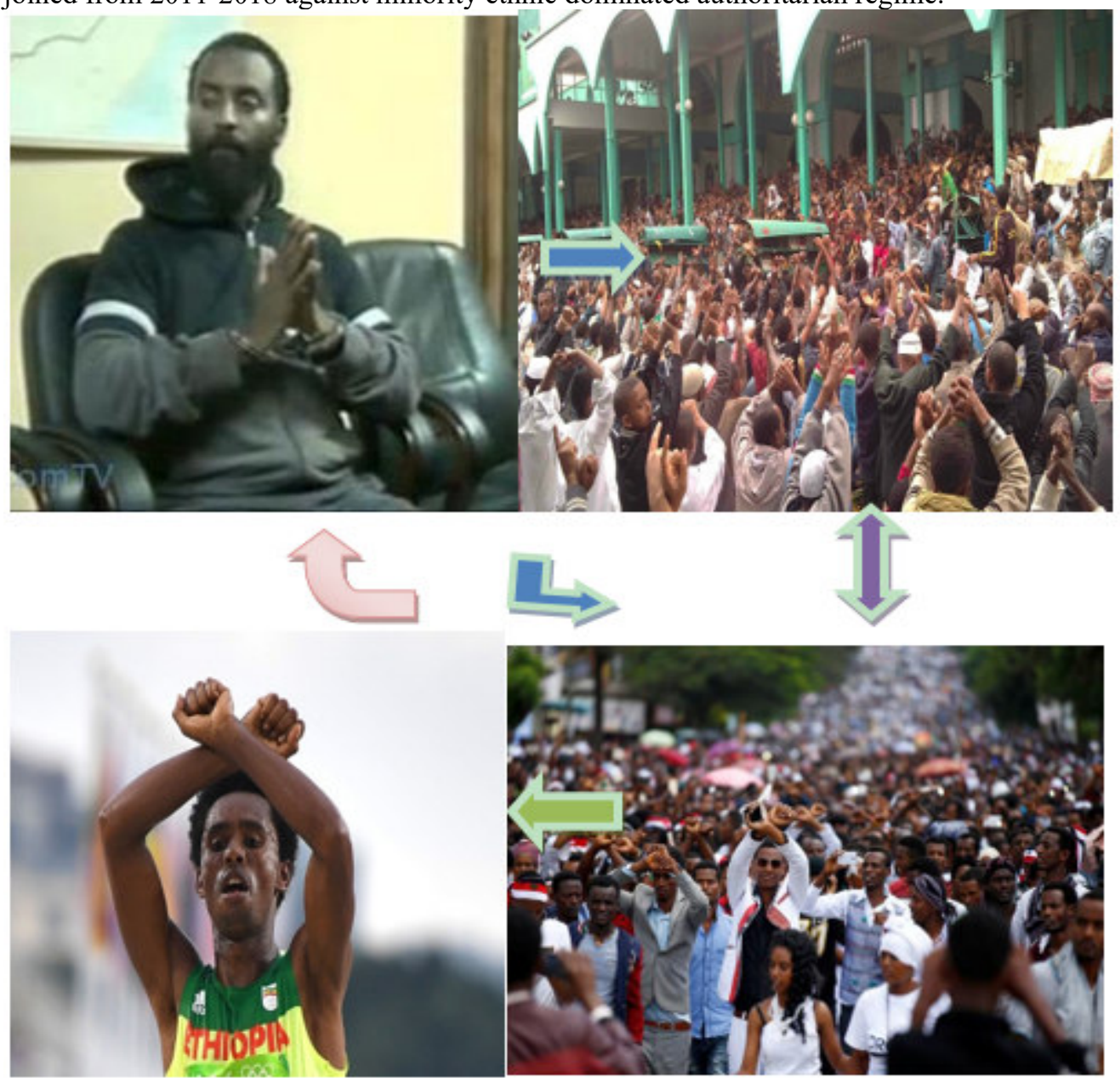

Figure 3, interplay of religious and ethnic based grievances adopting common symbol of protest. (The symbol From Etv leaked documentary, Mosques protest, Irecha Oromo Cultural celebrity, Rio Olympic, An ethnic Oromo athlete).

In this regard Lyons, $(2015,2017)$ argued that sustained from previously countrywide Muslim community's 
protest and fundamental grievances, Oromo and Amhara protesters has attracted "widespread international attentions when marathoner Feyissa Lilesa crossed the finish line at the Rio Olympics marathon and flashed the crossed arms symbol to show solidarity with the demonstrators".

Regarding the athletics event of the Rio Olympic, one of government affiliated Private Media Ms. Mimi Sebhatu, comment on her FM radio 97 that: "The symbol that Athlete Feyisa has showed during the Olympic race is the symbol of those extremist societies whom even the westerner's themselves considered as being in the process of radicalization", refereeing Ethiopian Muslims who introduced the symbol to resistance politics and the notion of radicalization and the proposal for moderating Ethiopian Muslims had come Western, particularly US. Accordingly the sign that the athlete displayed to international community was interpreted as as a manifestation and symbol of the trend of radicalization within Muslim community though the Athlete was not a Muslim and his concern was his ethnic Oromo protest.

In 2017 the public protest expanded to Somali and Afar regional states. While religiously these ethnic groups are entirely Muslims, they have been excluded from the central decision making process, only considered as affiliated to the vanguard party. An important religious issue channeled in the course of protest in these regions has been the prohibition of Mosque construction in the northern city of Tigrai region, Axum which is considered as a sacred city by Orthodox Christians. As $94 \%$ of the regional populations are adherents of Orthodox Christianity the ban of Mosque construction has always been refuted from Muslims across the country and some non-Muslim public figures. It has often been heard that the prohibition of mosque construction in Axusum incongruent with the existence of plenty of churches in the regions predominantly occupied by Muslims.

Another political heat in the country comes out from the birth of new more formalized ethno nationalism called National Movement of Amhara(NAMA) based on ethnoreligious discourses and revitalization old Solomonic narratives about the people of Amhara and its hegemonic, if not exclusive claim of the country's history and social fabric. While the notion of Amhara initially refers to adherents of Ethiopian Orthodox Chirstianity as understood by most of Ethiopians, the new political move to alter the historic religious notion and replace with ethno nationalism to fit the fashon of the day it has created a cultural noise among Muslims in Amhara region and wider Ethiopian society. The new movement of Amhara nationalism and its primodilization narratives faced massive resistances from Muslims in the region and other parts of the country such as people of Wollo and Raya who are mainly descendant of Oromo, Agaw, and Qimant ethnic groups from all of which the region's population built up through long historical and political interactions. The revival of Amhara identity as ethno nationalism founded on the historical Solomonic tradition of Orthodox Chirstinity and Amharic language as an ideological basis of imperial politics in the past, it doesn't give comforts to majority of Wollo communities whose ethnic background is predominantly Oromo and Muslims religiously. The role of religion is visible when Chirstians in the same area and common historical background of ethnic Oromo identified themselves as Amhara and expressed their sympathy to the new ethno nationalism. Muslims are indifferent to this assertion of Orthodox Chirstians as Amhara. Muslms and some chirstians who have sound understanding of Ethiopian history identify themselves as Muslim as a reaction to Amhara's earlier notion of Chiristian and Wolloye refereeing to Oromo's ethnic lineage respectively. Morover ample of politicians and acadamicicans have frequently heard saying that there is no ethnic group called Amhra in Ethiopian society ethnic landscape, emphasizing on the past usage of the word Amhara to refer the followers of Ethiopian Orthodox Christianity.

\subsection{Political Reform, Violence and Religion}

Current Ethiopian politics characterizes by greater ambiguity marked with hope and despairing features. On the one hand since the ascension of Abiy Ahmed as the country's prime minister in April 2018, new waves of national optimism has manifested in various ways. He has been taking several steps against the the policiecies of incumbent regime, wich he himself serve for long time, for two more than two decades. These measures include the release of several thousand of prisoners jailed in allegation to ethnoin and religious matters, opposition political party memberships and leaderships who wer victims of the regimes draconian anti-terrorism law, reform justice and security sector institutions and leaderships, held dialogues with religious communities to solve the problems in the previous years, increasing women's representations in key government positions and so on. On the Other hand, the country has been hosted a range of political crisis i.e. loses of human life, millions of internally displaced people and widespread unpredictability. Ethiopia has reported to be the first country in terms of internally displaced people in the first half of 2018, more than the world's worst scenario of conflict zones in Syria, Afghanistan and the Democratic Republic of Congo (The National, 2018).

Although political violence's and crisis have become common across the country, except in Tigrai region, the areas occupied by Muslim communities has been more plagued by displacement, death and brutalities than anywhere else. What nearly all the general public agreed upon is that all these violence both at the center and in the country's periphery are deliberately created by deep state establishments to destabilize the country and threatened the Western countries that there are Islamic extremist elements in the political turmoil. The notable one was the evictions of nearly a million ethnic Oromo from Somali region in 2017 and several thousands of 
Ethnic Amhara from Benshangul-Gumuz and Oromia regions. While the entrepreneurs of these conflicts were the security establishments who have left their official positions due to the new primeier's reform measures and the victims were from all religious communities, the intention of the former was to shape the incidents as interreligious conflicts to coincide the issue with global discourse of War on terrorism and Religious fundamentalism. The reason for this is that the Muslim dominated areas and regions in Ethiopia have always been distrusted in the eyes of Western country's particularly US. In his article Terrorism in East Africa and the horn, the US ambassador in Ethiopia from 1991-96 David H, Shine stated that constituting the largest Islamic population of any country in the horn of Africa region, a serious attention should be paid to Ethiopia as Muslims whose religious involvement has increased from time to time. He further argued that "the situation is further complicated because the largest ethnic group, the Oromo, who constitute about 40 percent of the population, is 55 to 60 percent Muslim" (Shine, 2003: 84). As members of the old security establishments who are pushed from the center are well aware of this attitude US, they prefer Muslim majority areas for their political business and conflict entrepreneurship. In this regard the Muslim communities have served as a hostage for regime's manipulation of US government's policy in Ethiopia and the broader Horn of Africa fiddling that if the Muslims in the region gain space, US will lose here interest in the ost strategic are of the World, the Horn of Africa. As a result Somali, afar, Oromia and Benshang regional states where Muslims share majority sections of the residents, have been the target to plot artificial conflicts and insecurities in order to tell Western powers the country's current political decay is due to fundamentalist elements among Muslim populations. On September 12, 2018 an US senior Analysist Emily Estelle, $(2018 ; 2)$ presented a written testimony on Ethiopia's security importance before the House Committee on Foreign Affairs Subcommittee on Africa in which he reported that "sustained conflict risks mobilizing Ethiopia's Somali population, potentially creating a new opportunity for al Shabaab to recruit or even expand its attacks into Ethiopia". In this case it seems the plot is going to work if the US and Western countries would continue to see the Ethiopian domestic politics in post 9/11 lenses when he further assert that "instability in Ethiopia will undermine US efforts to neutralize al Shabaab, al Qaeda's Somalia-based affiliate, and reverberate across the region".

As the new Prime Minister, Abiy Ahmed took a more aggressive approaches against the old security establishments, who were the beneficiaries of America's approach of supporting the strong, the latter exerted bigger efforts to fabricate political violence of religious characteristics miming on the discourse that the country is going to be like Libya, Syria and Yemen. To that end the old security establishment has created several conflicts and violence's of religious nature from the center to the peripherals of the country. In the late half of 2018, a group of people unknown to local Muslims come and destroyed the mosque and stoned Muslims in Adiss Ababa, Ashewa meda. While many Muslims and other observers claimed that the incident was done deliberately by security officers, the people who have engaged in attack run and sheltered themselves in the nearby Orthodox Church. Although the plot of creating large scale interreligious conflict had failed, the incident left many Muslims hurt and the mosque destructed. On June 26 a fire accident breakout in a midnight at Anwar mosque, often considered as Muslim's iconic heritage in Adiss Ababa which damaged women's madrasa part of the mosque and more that 50 electronics shops around the mosque. While there were not close investigations to the issue till now, there has been a widespread rumors that the accident was plotted by Tigrian People Liberation Front (TPLF) to create large scale violence of religious nature in order to get US on its side in domestic political crisis, an alliances over the last decades. Similarly in August, 2018 Mosques based violent incidents occurred in Northern central Ethiopia, Desse and Kombolcha by groups of people alien to the religious community in the areas. The most nefarious incident happened in Somali region, the third largest ethnic community whose entire members are Muslims in December, 2018 when seven Orthodox churches in the Jigjiga town have been attacked and set on fire, and seven priests and several members of religious community killed brutally (Aid to the Church in Need, 2018). Although Christians are not indigenous to the area and ethnically different to the local community the intention of the plotters to single out churches, clergy and Christians was to attract the attentions in a way that the attacks were not just ethnic-based but also religious extremism within Muslims. The government confirmed that the incident was mastered by the previous intelligence members and regional paramilitary forces, under the command of the regional president who was close to TPLF. What the incidents in the Somali region and violences in other parts of the country have in common is that all of them were engineered by members of the former security establishment to destabilize the country and challenge the new prime Minister's reform (Estelle, 2018).

The bold indicator of religious-ethnic marriage embodied in recently rising Amhara nationalism had noticed in the discourse of its militant faces and frequent complaints against Prime minister's positive measures towards Muslims. The hardliner nationalist, General Asaminew who was Amhara's regional security chief and was killed on 24 June 2019, as he attempted to escape after failed coup plot once said the problem Amhara people is facing today is more worse than the problem we faced five hundred years ago, implicitly refereeing to two great political episode of the time the defeat of Chirstian Highland Kingdom(Abysinia) by leader of Muslim, Imam Ahmed Ibin Ibrahim Al-Ghazi of Adal Sultanet and the advancement of Oromo population to the northern and 
central parts of Ethiopia in $16^{\text {th }} \mathrm{C}$. Moreover, in the video circulating on social media the same General advised the priests appearing in regional gathering to prepare themselves to be like Abune Petros, an Ethiopian bishop and martyr, killed by the Italian occupation forces in on 29 July 1936 for condemning Italian colonialism, and invasion of Ethiopia. While the bishop was from Oromo Ethnically, the Generals message explicitly conveys the resemblances of current ethnic strives with the religious skirmishes of $16^{\text {th }} \mathrm{C}$. Prominent Amhara nationalist and Orthodox religious leadership also has forwarded their feeling of discomfort and cautious about the Prime minister's permission of Islamic Bank and finance as an integral part the country's financial sector. While the Prime Minister's move to allow the opening of Islamic bank in Ethiopia is part of his measures to address grievances from all religious communities, the Orthodox Christian leadership has considered the premier's step as a special favor to Muslims. Similarly, the premier reunited the two disputing wings of Ethiopian Orthodox Churchs, one in the diaspora based in US for nearly three decades and the other in home based Ethiopian orthodox leadership, often accused for being affiliated with the regime. This and other measures of Prime Minister Abiy has credited by most Christians home and abroad. Despite the premier's positive moves towards each religious community, the century old tension and mistrust between followers of Orthodox Christianity and Muslims revived anchored in the destruction and demolition of religious institution, both church and mosque in different parts of the country.

\subsection{Domestic Actors, International Dimensions and Future Scenarios}

In a shrinking world local developments, from unemployment to ethnic and religious conflict are increasingly linked to distant conditions or decisions (Mcgrew, 2005). It is not to make a claim that all ethnic and religious conflicts and instabilities in Ethiopia have international dimensions, but to illustrate some connection with external environment and parties. The international dimension of religious politics in Ethiopia is not a new phenomenon rather deeply rooted in the whole gamut of statehood formation. A close examination of contemporary patterns political interactions in Ethiopia reveals three categories of actors, defined by blurred ethno religious motives through which the country's future can be read. These are Orthodox Christianity, Islam and Protestantism and each of them has strong bases in specific ethno territorial and sub territorial units and political interests at national level. All these groups hold different political attitudes, sets of political values about the fundamental goals of Ethiopian politics. The positions of Orthodox Christianity, Islam and Protestantism defined by hegemonic camp reactionary, Resistance and revolutionary stands respectively coincided with particular ethnic or sub ethnic groups political interests and stands.

Hegemonic and reactionary camp: These are a group of political forces who seek to restore political, social, and economic institutions and national identity of the state as defined during imperial time. These groups are mainly represented by Orthodox Christians and Amharic speakers with main territorial basses in Amahara regional state of the current federal structure and elsewhere in the country. This camp propagates the idea that the historical Ethiopia was so great and they have to make it great again. According to this group all the political problem the country faces today are the result of ethnic federalism and the current constitutional order. They accused the system to its emphasize on ethnic and linguistic group rights which according to them weakens the state by encouraging divisive agendas. This idea holds by various political groups and movements including those who favor strong unified government and citizenship politics and emerging Amhara nationalism. While advocates of citizenship politics urges to change the country's federal system and constitutional order, the Amhara ethno nationalist attempt to redefine the old religious notion of Amhara in terms of ethno-linguistic identity for the purpose of political mobilization. However, the new move to define Amhara in terms of primordial ethnic sense faces controversies as it creates cultural noises from different ethnic groups in the region and religious community throughout the country. Although Orthodox Christianity is dominant in both Amhara and Tigre ethnic regions in the North and Northern central parts of the country, the Tigrians rarely manipulate the religion to support their political agendas at national level. Generally these political forces want to the revive the establishments anchored in Orthodox Christianity as the official state religion of the state as it was from $4^{\text {th }}$ century to 1974 Ethiopian revolution to serve as a source of ideological lenses to politics and to define the country's national identity as in the imperial times. These groups felt threatened and become reactant to most of new developments in the recent history of the country particularly the increasing involvement and visibility of Muslim's in socio-economic and political life of the country and the spontaneous spread of Protestantism to which several adherents of Orthodox Christianity has converted to.

In the course of domestic power competitions with other section of the society particularly with Muslims this group has been sought external support and cooperation from different outside forces. The external relations of hegemonic preservation movements have three main dimensions: to the western world, Israel and recently Russia. Using vast number of diaspora communities in US and European countries this bloc tried to utilize the post 9/11 international environments and global security discourses by associating and depicting the civil right movement of Ethiopian Muslims, politically active and engaging Muslim individuals as Islamic movements to establish religious oriented politics in Ethiopia. In fact this discourse was fruitful to the enormous financial and 
military support the TPLF lead government had gained from US and EU for the last three decades in the name of fighting terrorism in the Horn of Africa region. The second presumed source of hope and support for this group of political forces is Israel. Despite the religious teaching of Orthodox Christianity cursing Israel for presumed refusal to accept Jesus as the Son of God anchored in the mythical book called Kibre Negest(Glory of Kings) as "the foolish Jews, who are blind of heart and enemies of righteousness," 1 did not "comprehend the Gospel of Jesus and in their evilness they murdered him" (quoted in Erlich, 2013:14 ), politically they associate Ethiopian state to today's state of Israel through historical familial lines. The discourse is based on the biblical myth about the visit of the Ethiopian Queen of Sheba to Jerusalem and her meeting with King Solomon, from whom she got a son called Minilik, who become the first emperor of Ethiopia and founder of Solomonic dynasty. Recently many Orthodox Christian religious activists are circulating messages of support and sympathy from Russian government. The closer examination of this group's approach to domestic politics reveals that the ultimate political end is to preserve historical hegemonic status of Orthodox Christianity and Amharic language as the sole definer of Ethiopian national identity.

Revolutionary Bloc: This block is represented emerging rise of Protestantism in the past three decades that has challenged Ethiopia's old religious landscape matrixes considerably. First entered Ethiopia in 1950 through Swedish and Finish missionary activities, Protestantism brought a new pattern of religious factor in Ethiopia, which attracts considerable public attention, influences social behavior, even and invites disputes with already established religious community (Elliesie, 2014). Protestantism highly spreads in the Southern Nations, Nationalities, and People's Region (SNNPR), western and central Oromia, Gambella, Benshngul and in urban areas around the country. Besides increasing social dynamic, Protestants become active in politics with considerable number holding governmental offices ministers sometimes outnumbered Orthodox Christians and Muslims. There has been frequent gripes in the circle of Orthodox Christians that the regime is favoring Protestantism as religion and protestants in the politics and bureaucracy to pleased western countries particularly USA. In this regard a great deal activism on social media sought to associate the election of the new Prime minister has with some religious significant when they blame US government's interest and influences in the nomination of Abiy Ahmed as Prime minister. Although the prime minister has come from the region where Muslims are majority his political discourses and choice of his co-religious Oromo to several important governmental posts have been points of informal discussion among Muslims and Christians altogether. In relation to this On January 3, 2019 the New York Times read about the new Ethiopian prime minister as "Abiy is constantly invoking religious symbols; especially those linked to American Protestant evangelical mega churches, and has brought a greater number of Pentecostals into the higher ranks of government". Having enormous support in finance, scholarship and diplomatic influences from Western, mainly US based evangelical Christian groups the purpose of this group is to transform the country's socio-political the way it serves their religious community.

Dissident Bloc: This block is represented by Muslims of all ethnic background across the country, who sought to challenge the established national doctrines, institutions and policy looking for more open and inclusive socioeconomic and political conditions. With long history of multi-dimensional marginalization in Ethiopian polity, Muslims have been struggling to get full fledge communal and citizenship status, demanding more religious rights and political inclusions. Islam is established within greater sections of Oromo Society, entire Somali, Afar, Harari, Silte, ethnic groups, Wollo and Benshangul areas. The political interest of this group is to redefine the country on inclusive bases and political participation to increase its share in country's decision making process. The discontent of ambitious Muslims is not limited to domestic politics, but has international dimensions. With increasing number of Muslims academic exposure and knowledge of international politics and order Muslims are unhappy about the external world political sphere due to the fact that there is no any international actor that either welcome or support their domestic agenda and struggle. However, there is long tradition among Christians that Ethiopian Muslims might get political support from neighboring Muslim countries and Gulf States. The feature of this group's external relation depends on whether the global contexts bring alternative emerging powers with political agenda abroad.

\section{Future scenarios}

Although the official structure of Ethiopian politics bases on ethnicity, there are many synergies between religion and ethnicity as outline above. This domestic reality in consort with external players and interests will determine the fate and future of the country. The reason for this goes both to domestic conditions of shifting from ethnic to religious loyalty, though hidden in ethnic political discourses, the country's historical experiences and strong interests of external actors obsessed with religious factors both in Ethiopia and in the broader region of the Horn of Africa. Short lived cooperation of different religious and ethnic based aspiration in the previous years flawed, were only due to mere common antipathy towards the government dominated by a minority Tigre ethnic group. After the relegation of common enemy, TPLF such alliances between religious and ethnic based grievances and interests in the struggle against government, have replaced with tensions of ethno-religious 
character that has often manifested in the ongoing country's public sphere and polemical circulation of narratives on social media, destruction and demolition of religious institutions which might turn into violent confrontations in the near feature. Thus in Ethiopian contexts of pluralism ethnicity and religious are essentially twisted where one serves the other in the process of political bargaining and expression of interests. All these organized and countrywide protests resulted in the political transition within the existing system and regime's establishment. There are different perspectives on who are the main actors or factions at play in the country's political transition, speculations ranging from USA involvement either directly or indirectly through Saud Arabia and UAE to the shift of domestic power balances along with elites who sought to use public protests for political bargaining within the party. Regardless of the absence of this clarity, one thing has assured that the minority Tigrain groups who had dominated the government and state apparatus for at least three decades has lost their status with the coming of the new Prime Minister from Oromo ethnic group and protestant by religion. The relegation of Tigrian people liberation Front(TPLF) from its dominant position with in EPRDF government has been creating a sort of Post-TPLF EPRDF rule with the creation of new party called prosperity party by Prime Minister Abiy Ahmed. Despite the fact that the struggle of Oromo nationalist brought Abiy Ahmed to Power, he has been accused for his sidelined moves to major questions of Oromo people articulated as: ownership of the Capita city Adiss Ababa which was established on the historic Oromo land by emperor Minilik II, to make Afan Oromo the working language of Federal government along with Amharic, the issue of equal representation in federal bureaucracy and fair resource allocations. On the other hand the recently emerged Amhara nationalism accused the Prime Minister for his supposed favor of his own ethnic group and religious community and Western agenda in the country's socio-political life.

The country's worst and best case scenarios will be determined by patterns of local actor's commitment to political process of bargaining and its interactions with the policies, positions and interests of outside actors. To start with optimistic estimation, the best case scenario of the country's upcoming fate, though rare is transition to inclusive centered, balanced and democratic politics and building of strong institutional frameworks. The establishment of strong and inclusive institutions can only limbering down the heat of identity politics of whatever ethno religious forms. There must be strong institutions that people can trust for their own security to move away from group thinking and mass political actions. However, the current conditions of security dilemma is reinforced through not only the absence of inclusive institutions to protect people from violence perpetrated by local ethno-religious foes, but also due to paralyzed condition of the existing institutions to safeguard people and ensure rule of law. In this regard there is little hope from domestic sphere towards genuine political bargaining given the wide divergent of interests of political and petite willingness to sit together and narrow down the conflictual positions. Ironically, rather than working to find solutions of the country's political crisis, most political forces prefer outside in approaches, looking external partner and assistance to win over domestic contradictions using different global and regional contexts such as presenting the issues as a problem of Islamic extremism to international community. So far the position of outsider actors, particularly the Western governments is not clear whether they will continue to make and support their own strong or to facilitate genuine transition to democracy based on local realities and Ethiopian context. Since the coming of the new Prime minister the Western support has been taking the form of financial and security and intelligence assistance to reform initiatives with the new leadership.

The worst case scenario that could happen to the country is balkanization that might make the country African Yugoslavia whereby each competing political forces claims to create its own independent state. This process will not be easy as separatist movements will fight to blood over ownerships of territory and resources and would be exclusive claims of some areas to particular ethno-religious community. Indeed the process will accompany through genocide and bloodsheds. Local conflicts, the way they outbreak, unfold and persist are mirrors of global trends and dynamics of great power competition and relations and indicate the issues which the international actors is obsessed with are in indifferent (Malley, 2019). Because of this it might be essay to guess who will stand with whom in the upcoming conflicts in Ethiopia if the logic of balance of power on which the global order had once been understood continue to work. However, the already existing geopolitical trends of the horn of Africa and the domestic conditions of Ethiopia might mislead the outside actors' line of support and inflated expectations of outside support also mislead local actor's political calculations to conduct genuine political bargaining based on local realities and circumstances.

\section{Conclusions}

This article has sought to clarify the confluence of ethnicity and religion in the view of ongoing Ethiopian political crisis and tried to indicate some future scenarios. It has argued that the official Ethiopian ethnic politics has tacit religious dimensions intertwined in historical political landscape of the country and contemporary global contexts. The country's ethnic based federalism creates ethno territorial autonomous unites which also defined by patterns of religious sceneries. Despite internal rivalries and conflicts among different ethnic and religious groups throughout the country's history, Ethiopians have never compromise their country's national 
integrity to foreign agendas of any kind. Contrary to this fact, nowadays the country faces problem of political crisis that often take ethnic and religious character, which are colonial origins in other African states. The overlapped nature of ethnic and religious identities in most parts of the country, political crisis and its ethnic formula by default has religious perspectives that increased the attentions of international actors in the contexts of post 9/11 global political winds. While the internal politics favors ethnicity over religion as a formal means of political mobilizations, the post 9/11 international and regional circumstances and its translation to domestic environment become the point of intersections where ethnicity and religion blurred together. Thus the country's ethnic based politics and interethnic tensions and violence has extended explanations of religious factors which often influences the interactions of domestic political actors and their behaviors and the way external actors approach to Ethiopian politics. Although religion has never been issue of formal and open political debates, religious interests often manifested interwoven with ethnicity. Furthermore, the post 9/11 international contexts of Global war on terrorism have been utilized by Ethiopian regime to suppress ethnic grievances and gain ideological, material and financial supports from the US government. While the primary concern of security understanding, policies and practices should be domestic politics and contexts, the Ethiopian government's securitization approaches to ethno religious identities have incurred costs of destabilization that darken the feature of the country and its survival as a state in its present form. The ongoing political crisis and instability in Ethiopia are driven by a mixture of ethnic and religious motives that traced back to confrontations between Muslim community and the EPRDF government in 2011. The feature of the country will largely determine by the interactions of these factors and how the international actors will approach to the domestic realities. Thus ethno religious diversities, century old politics of marginalization, and attempts of willingness on the part of the government to restrain ethno religious grievances are most likely to risk the country for interventional manipulation, intervention and destabilization.

\section{References}

Abbink, J (1998). An Historical-Anthropological Approach to Islam in Ethiopia: Issues of Identity and Politicsll, in Journal of African Cultural Studies, Vol. 11,

(2011) Religion in Public Spaces: Emerging Muslim-Christian Polemics in Ethiopia. Oxford University Press, African Affairs, 110/439 No. 2, pp. 109-124.

(2014).Religious Freedom and the Political Order: The Ethiopian Secular State 'and the Containment of Muslim Identityll, in Journal of Eastern African Studies. pp. 1-20.

Aid to the church in Need (2018). ETHIOPIA, 10 Churches burned, 30 killed including 6 priests in Somali Region. Retrieved from < https://www.acnmalta.org/2018/08/13/ethiopia-10-churches-burned-30-killed-including-6-priests-insomali-region-acn-malta/ $>$

Dereje Feyissa (2010) "Setting a Social Reform Agenda in the Homeland: The Identity Politics of the Ethiopian Muslims in the Diaspora", Diaspeace WP3 Working Paper.

Ethiopian Muslim arbitration committee letter to President Obama, President of the United States of America, October 22, 2014. Posted by: ecadforum October 30, 2014

Henok,N(2013).Audience Reception Analysis On —Jihadawi Harakatl Documentary Film Among Addis Ababa Communities.MA thesis Adiss Ababa University, Faculty of Journalism and Communication, Unpublished source.

Information Network Security Agency (INSA), the Federal Police Anti-Terror Joint Task-Force and Ethiopian Radio and Television Agency. (2013). (Producer, Director, Writer). "Jihadawi Harakat" [Documentary]. Ethiopia: ERTA (http/www.sodere.com) accessed 25 February, 2016.

International Crisis Group (ICG). Ethiopia: Governing the Faithful Crisis Group Africa Briefing $\mathrm{N}^{\circ} 117$ Nairobi/Brussels, 22 February 2016.

Jawar Mohammed speech at the commemoration of Ethiopian Muslims nonviolent struggle in Washington DC on January 262013.https:/www.youtube.com/watch?v=7WNe56XcVG8 last accessed 5/28/2017.

Jawar, M (2012) Growing Muslim Activism and the Ethiopian State: Accommodation or Repression?\| April 04, 2012

Joseph Ruane \& Jennifer Todd (2010) Ethnicity and Religion: Redefining the Research Agenda, Ethno politics, 9:1, 1-8, DOI: 10.1080/17449050903557377

Larzillier, P(2012). Production of Norms and Securitization in Development Policies: From Human Security to Security Sector Reform.the Issam Fares Institute for Public Policy and International Affairs, American University of Beirut.

Lyonse, T (2015). The Arab Uprisings and Ethiopia: Diffusion and Local Models. AUCP Workshop, ISA.

Malley, R(2019). 10 conflicts to watch in 2020. Foreign Affairs

Muhamed, D (2016).Contested Secularism in Ethiopia: The Contention between Muslims and the Government.PhD dissertation, Adiss Ababa University. School of graduate studies. Unpublished material.

Muhamed, Dejen (2015). Secularism and Politicized Faith in Ethiopia.2015, Tana Forum University Essay 
Competition Essay No. 2.

Muhammed Ali Alula al Hashimi (2013) .Ethiopian Muslims and the Ahbash Controversyll in the Civil Rights Movement of Ethiopian Muslims: Context, Defining Features and Implications (Selected Articles), LEBMA vzw, Belgium.

Mukerem, M (2015).At Issue: The -Muslims in Ethiopia Complexll and Muslim Identity: The Trilogy of Discourse, Policy, and Identity.African Studies Quarterly | Volume 16, Issue 1.University of Florida. ISSN: 2152-2448.

Østebø and Wallelgn (2015). The Intellectualist Movement in Ethiopia, the Muslim Brotherhood and the issue of Moderation. Norwegian Peace Building Resource Center. NOREF Report

Ostebo, T (2007).The Question of Becoming: Islamic Reform Movements in Contemporary Ethiopia. CMI Working Papers, Chr, Michelsen Institute, Bergen.

Ostebo, T (2013). Islam and state relations in Ethiopia: From containment to the production of a governmental Islamll. In: Journal of American Academy of Religion, Vol. 81, 2013, pp. 1029- 1060.

Serawit Bekele Debele (2018) Religion and politics in post-1991 Ethiopia: making sense of Bryan S. Turner's 'Managing Religions', Religion, State \& Society, 46:1, 26-42, DOI: 10.1080/09637494.2017.1348016

Shinn, D. H. (2003). Terrorism in East Africa and the Horn: an overview. Journal of Conflict Studies, 23(2).

The National (2018). Ethiopia has highest number of internally displaced people in 2018. $<$ https://www.thenational.ae/world/africa/ethiopia-has-highest-number-of-internally-displaced-people-in2018-1.769626>

The Newyork Times, January 3(2019). Opinion The Trouble with Ethiopia's Ethnic Federalism accessed from < https://www.nytimes.com/2019/01/03/opinion/ethiopia-abiy-ahmed-reforms-ethnic-conflict-ethnicfederalism.html>

McGrew, A. (2005). Globalization and global politics. The globalization of world politics, 3, 19-40.

Jonathan C. Agensky (2019): Evangelical globalism and the internationalization of Sudan's second civil war, Cambridge Review of International Affairs, DOI:10.1080/09557571.2019.1632262 